\title{
Women and the Perpetuation of Caste System in Nepal
}

Mira Mishra

\begin{abstract}
South Asian feminist scholars have attempted to comprehend both the nature of interconnections between caste and gender relations and women's complicity in sustaining patriarchy and caste system. This presentation seeks to answer a few key questions regarding the interconnection between caste and gender. It also seeks to answer the question regarding how and why women in Nepal wittingly and unwittingly help maintain the caste system that underlies their own subordination. The answers are framed within the ongoing dynamics of society in Nepal.
\end{abstract}

Keywords: caste, gender, women, sexuality, role, marriage, occupation, kitchen, menstruation

\section{Introduction}

I begin this presentation with my personal experience with caste and gender. I was born and brought up in an extended, patrilineal and patrilocal Brahmin household in Kathmandu. Caste and gender hierarchies were strong in everyday life. My grandfather and his brothers had the major say in the household. My grandmother, mother, and aunts were also active agents of the system as they motivated, taught and socialized us to adhere to gender and caste norms, particularly the rules on purity and pollution, including those related to food and sexuality. For example, they socialized us on how to exercise control over one's food items and eating rituals. Sexuality was controlled by restricting one's circle of potential friendship. They socialized us primarily through stories and conversations. Marriage and caste were the central issues of household and "womanly" conversation.

My experience as a growing girl refers to late 1960s and early 1970s. The 1963 Civil Code delegalized the caste system and "untouchability". It nonetheless could not substantially alter norms and practices regarding caste hierarchy in our household and many others like ours. From everyday practice and listening to the conversations among adult women who were anxious about maintaining such rules, I learned the rules of caste.

In 2007, when my daughter had completed her high school and was leaving home for study, my mother, who was in her early 70 s, took the role of counseling her. The counsel was loaded with caste norms and values. My mother, who had strenuously and unfailingly attempted to maintain such rules, was happy that her granddaughter was going out of the country for further studies but also tense was that she was not going to a place where caste rules could strictly be followed up. She told my daughter:
I am happy that you are going abroad for higher education. You must excel in education and earn on your own because this is not our jamana (time). At our time, girls neither thought of going to school nor earning by themselves. Many young women are now going to foreign countries for study nowadays. Nonetheless, young women are marrying anyone, even with a foreigner. They don't care about jat (caste). You should yourself marry with a Nepali not a foreigner. If possible, you should not marry a Janajati or a Newar. I have heard that a Brahmin girl can't adjust in a Newar household because they perform rituals different from ours.

My daughter, however, was quite different from me by teen age. Although she did not say anything against my mother's counsel she laughed out loudly. She was, unlike me, raised in a small family with more liberal views on caste. Her youth and schooling also helped her grow with more liberal views. By the time she was ready to leave Nepal for further studies she had already become liberal. Later, in 2018, when she was ready to get married, the caste dimension was revived among relatives and friends. The groom belonged to a Brahmin family. Besides, he had several important qualities that made him suitable for the marriage. My husband and I hoped that our daughter would marry a Nepali man. Caste, however, was not a consideration for us. We knew well that it was our daughter who ultimately would decide who to marry because she was educated, earning by herself and, most importantly held liberal views on caste. As compared to my mothers' time, the salience of caste has considerably subsided not the least because more young girls now enter into love marriage (Mishra 2014). Nonetheless inquiries made to us by relatives indicated that they were much interested about the caste affiliation of the groom - although the interest also spanned other areas like schooling, job, etc. One of 
our adult male relatives said:

We had thought that Prakriti would marry someone else. She has been living for so long outside of the country. She is a very open-minded woman. You are so fortunate that she is married to a Nepali, and an educated, employed and, importantly, also a Brahmin. These days, young women, even in Kathmandu, marry grooms from different caste groups. Parents have no say on their children's marriage these days.

Many adult women relatives and friends shared similar views. The intensity of caste related sentiment is reflected in the views of a woman student from a Gender Studies class I teach. She said:

I have a Dalit friend who was in a committed relationship with a Chhetri man for almost five years. Both of them are educated and employed in an INGO in Kathmandu. When my friend insisted her boyfriend marry her, he did not reply. When she went on insisting, he told her that he could not marry her because his parents would refuse to accept a Dalit woman as a daughter-in-law. He also told her that he could not stay separately from his parents. The two had heated discussion for some times. At long last, my friend decided to end the relationship.

These accounts are indicative of the following. First, caste continues to play a significant, although not central role in Nepal. Second, there is a growing tension within "high caste" families to maintain the caste system. Third, marriage between a Dalit and a non-Dalit continues to be a far cry.

As such, the central questions this paper asks are: (a) In what ways do Nepali women contribute to uphold the caste system? (b) Why do they do so? (c) What gender and caste-related changes have been taking hold over the last two decades? Finally, (d) What are the factors that are contribute to the changes?

\section{Feminist Theorization on Caste and Patriarchy}

South Asian feminist scholars have been illuminatingly explored the interconnections between caste and gender relations. In addition, they have explored mechanisms that are utilized to sustain sexual and caste purity and women's complicity in sustaining both patriarchy and caste system (Mishra forthcoming). A number of authors have written on the role of women in sustaining the caste system (Chakravarti, 2004; Dube, 1997; Khanna \& Price, 1994). It is, therefore, essential to explore the relationship between caste and gender in general and women's role in maintaining caste system in particular.

Caste and gender hierarchies are mutually interlinked. Control over female sexuality is central both to patriarchal and caste relations (Beteille, 1990; Chakravarti, 2004; Chowdhary, 1997). Beteille (1990) argues that gender asymmetry in general and the control of "upper caste" men over "lower caste" women go together. Beteille further argues that societies that are characterized by gender asymmetry are also those which uphold more stringent rules to maintain the caste system (1990, p.492).

Chakravarti argues that in South Asia, women's sexuality was utilized to preserve both a caste and class based society. Regulation of marriage and sexual relation is the primary means utilized to maintain caste boundary (Chakravarti, 2004; Chowdhary, 1997). Chakravarti, in addition notes that early marriage and strict social and religious codes related to sexuality for women, particularly "high-caste" women were the principal mechanisms that ensured the sanctity of caste and caste boundary. For women, marrying "lower-caste" men was highly stigmatizing. Therefore, both "higher caste" women and "lower-caste" men were kept under the strict control of "high-caste" men and the society they led (Chakravarti, 2004). Khanna \& Price (1994) discuss factors such as class, religion, caste, and ethnicity which are utilized to varying extents to manage and control female sexuality. Nath (2012) argues that religion and state are the major institutions that perpetuate patriarchy and women's subordination. The studies by Bennett (1983/2002), Cameron (1998/2005) and by Kondos (2004) in the context of Nepal also reach similar conclusions.

It may be noted that South Asian feminists have explored the control over women's sexuality much more intensively as compared with issues such as interconnections between caste, gender and economy (Cameron, 1995), women's resistance against control (Khanna \& Price, 1994), and women's role in maintaining the caste system (Dube, 1997). Khanna and Price, in this connection note that "sexuality has often been regarded as a source of male power and female oppression. Women's agency, for example, of resistance against the control, has largely been ignored" (1994, p. 34). Cameron's views are supported also by (Aloysius, Mangubhai and Lee 2011, p. 5) who argue that "understanding of the inter-linkage between caste, class and gender is imperative".

Chakravarti (2004) has argued that examining women's status has long been the practice of South Asian scholars to explain gender equality. Nonetheless, it cannot explain the relationship between caste and gender. She notes that it is far more important to examine the institutional basis of women's subordination than to merely discuss women's status. Nath (2012), however, cautions that in more recent years the focus had been shifting from an emphasis on status of women to structures of women's subordination. Cameron (1995), on the other hand, adds that South Asian writings do not adequately address the relations between caste, gender and economy.

Rao (2005) further notes that due to modernization and democratization led changes in the caste system, there has been a fundamental transformation including in the fields of caste and gender relations. She adds that caste as such survives but gender and sexuality has been reshaped. She accepts that caste system subordinates both upper caste and lower caste women. Upper caste women are overburdened due to their supposed responsibility of preserving the caste system by maintaining chastity and purity of the body (2005, p. 715). Nath's (2012) explanation makes Rao's argument much richer. Nath takes a class position 
to discuss on why "upper caste" women are constrained by their relative caste and class position. He notes that due to economic necessity, "lower caste" women were more intensively engaged in productive activities than "upper caste" women. Engagement in productive activities, in turn, provides the "lower caste" women with an enhanced measure of freedom. As such, he argues that economic freedom could also free women from patriarchal and caste control.

Chakravarti (2004) further argues that control over "upper caste" women's mobility and sexuality is the key to sustaining the caste system. Sindhe (1982 as cited in Rao 2005, p. 715), on the other hand, views caste-based society from a different angle and holds that women not only suffer from but also perpetuate the caste system. Lerner's view in Creation of Patriarchy (1987) that women voluntarily participate in sustaining patriarchy fits in with Sindhe's argument. Dube's work, in turn, is arguably the richest work so far in discussing on the role of women in upholding the caste and patriarchal system (1997, p. 6). She notes that every caste or jati has a specific culture and ritual that imparts them with a sense of common identity. These cultural identities are learnt at home and within the kin network. Organization of the space, rules of purity and pollution, mode of fast and worship, etc., are the principal sites and mechanisms of women's complicity.

Lerner (1987), Chakravarti (2004) and Dube (2001) agree that most women are compliant to and serve as agents to sustain caste and patriarchy. But they do so in different ways. Lerner notes that women do so because a subordinate position provides women with protection and privilege. Chakravarti maintains that women sustain caste-based patriarchy because of internalization of patriarchal values (2004). Dube's socialization-based analysis of the control over women's sexuality, in turn, makes Chakravarti's analysis much richer (2001). Dube notes that from the very early years, girls are socialized to ingrain patriarchal norms and values in India. Chakravarti fills in by elaborating the mechanisms through which women's cooperation in sustaining the caste system is ensured. These mechanisms include ideology, economic dependency of women on men or other household heads, class privilege and the use of force if and when women disobey associated rules (2004).

Many authors have recorded changes in the caste system due to the changes in the larger socioeconomic dynamics of South Asian societies (Chowdhry, 2009; Datta, 2015; Dube, 1997). Datta (2015) interprets caste as "a form of "human made" exploitation and hierarchy, which has insidiously used the ideological masks of karma and dharma to deny humanity to an overwhelming majority of South Asians. Chowdhry (2009) follows up by identifying features of the changing nature of Indian societies in general and caste relations in particular. She argues that due to the changes in the material, legal and ideological bases in post-colonial India, caste relations in particular have weakened. She also links such changes with the anxieties of dominant caste groups who are fearful of mixing of the castes due to such changes. Fear, in particular, has been associated with marriage between the Dalits and non-Dalits.

The arguments put forward by South Asian scholars fit in closely with the changing socioeconomic dynamics of Nepal in general and the rural areas in particular. Nepal in general and rural Nepal in particular is transforming rapidly (Mishra, 2013) with the diversification of modes of generation of livelihood (Mishra, 2019; Adhikari \& Hobley, 2015). It is characterized, among other, by increasing engagement of women in changing rural livelihoods (Mishra, 2019). A qualitative study with 50 rural women in the south-central Inner Tarai of Nepal carried out during 2012-2013 revealed that rapid rural transformation started after 1990 and got apace following the end of Maoist armed conflict in 2006. The changing perception of rural residents is reflected in the account of a Tamang man in his late $60 \mathrm{~s}$, who had been politically active for a long time: "Two significant changes have occurred in this village over the last 25 years. First, women have started coming out of home. Second, Dalits have begun to enter into high-caste homes."

A middle-aged, "high-caste" man, who is a primary school teacher, said the following in relation to the changing gender and caste relations:

Every outside developmental organization that comes to our village to introduce a new development or rights program seeks out women first. These institutions then seek out Dalits and, sometimes Janajati in order to run their program. We are nowhere these days. Our time has gone (Mishra, 2020 forthcoming).

I earlier drew from the theoretical discussion that there is a strong connection between caste and gender. The caste system sustains by controlling women's - particularly "upper caste" women's - mobility and sexuality. Nonetheless, a caste is not a fixed entity. Changes in the larger society and economy have led to changes in the nature of the caste system. The interconnection between patriarchy and caste, therefore, is less intense in societies which are undergoing large scale socioeconomic and political change. Caste and gender asymmetry shrink in locations and times that are undergoing transformation.

Informed by this theoretical discussion, I have tried to analyze changes in contemporary Nepal from the gender and caste perspectives. On the one hand, women's lives are changing in a positive direction as more women are educated, earning and pushing themselves to leading roles than ever before (Mishra, 2019). Women's public-ness has substantially increased. Exercise of life choice, including marriage decisions has widened. Women are coming out of home to engage in public arena as students, teachers, job holders, members of savings and credit groups, political cadres and representatives, etc. The increasing access of women to schooling is one such example. Before 1950 , only two percent of women were literate. Now the proportion has exceeded 50 percent. Importantly also, the proportion of women supersedes men at Grades 11 and 12 (Parajuli, Upreti \& Onta, 2016). As Chanana (2001, p. 39) notes, formal schooling reduces the control of a family on 
girls and women as it involves a move on their part into the public space, interacting with men (in coeducational schools with boys and male teachers), socialized into the curriculum along with boys and moving away from the eventful goal of wifehood and motherhood. Women's nonfamilial experience has an important effect on their choice regarding age at marriage, type of marriage, and spouse selection (Ghimire et al., 2006). All of these changes are particularly true for younger women. Private patriarchy, in essence, is gradually weakening (Mishra 2018, 2014).

\section{Method}

This article is primarily based on the interpretation of women's experience of caste. The author's personal experience of caste and changes and continuity in the caste system that she experienced during the last three decades, in turn, has shaped this interpretation. Her previous works (Mishra, 2011, 2015, 2018, 2019) provide further groundwork for this article. During fieldwork she engaged in extended conversation with women of different generations, caste and class groups as well as geographical locations to understand the changes in the lives of women. Besides, she drew from reviews of various literature related to caste and gender in South Asia and Nepal to comprehend and analyze women's role in sustaining the caste system in Nepal.

As a feminist academic, respect towards my subjects was of utmost importance to me. Consent was very important as well. The consent was verbal but it was sought with due seriousness and was offered with full seriousness as well. The privacy of subjects was also of prime concern. I have used pseudo names while documenting personal accounts.

\section{Prime Sites of Caste and Gender}

Despite the large scale transition in women's lives globally, women spend more time at home than men in Nepal as elsewhere (Acharya and Shrestha, 2018). It is necessary, therefore, for us to identify and review the nature and dynamics of social sites from where women act out to sustain caste and patriarchy. I attempt here to review such agency among women with reference to four such sites, the kitchen, occupations, menstruation, and marriage.

\section{Kitchen}

"Food constitutes a critical element in the ritual idiom of purity and pollution ... the task of safeguarding food, [and] averting danger... falls upon women. There is a relaxation in the public arena but home is still the custody of women" (Dube, 1997, p. 6). This holds true for women in Nepal as well. The kitchen has been the key locus for creating, maintaining and negotiating ethnicity and castebased practices and hierarchy in Nepal. Women continue to act as the active preservers of such rituals and hierarchy because women spend more time in the kitchen than men and visualize themselves as the prime agents of the kitchen. Even as kitchen is a site of subordination for many women because it demands so much time and energy while at the same time that it is financially and socially unrewarding, the kitchen is also a source of power and security for many others. It is the locus where women are free to do what they want, and they can, if they so wish, to manipulate men through cooking and feeding. Women in the middle and older generations in particular imbibe pride in socializing young girls on caste and ethnic purity through kitchen rituals. A middle-aged Tamang woman from the central Inner Tarai - where I worked during 2012-13 - noted that women, not men were the preservers of their caste. She noted:

Men are free people. A woman, on the other hand, should teach their children about the ethnic and caste-based rituals and train them, particularly daughters, so she can lead a respectful life when she is married. Raksi banaune hamro jat le nai ho; hamile chhori haru lai sikaunu parchha (It is our ethnic group that has been charged with preparing alcoholic beverages. As such, we have to teach it to our daughters). Marda parda, jay ma pani hamilai rakshi nai chahinchha (We need such beverage during all rituals, including the death ritual). If women don't know how to make the beverage, she can't thrive at her affinal home. (Mishra, 2015, pp. 98-99)

Similarly, Priti Bania, a middle-aged Chhetri woman passionately noted the exclusive nature of caste distinction thus:

We Chhetris are lower than Brahmins but higher than all other ethnic and caste groups. Hamilai bahun ko bhat bhancha chalchha, bahun lai hamro bhat bhancha chaldaina, kinaki bahun haru hami vanda badhi suddha hunchhan' (We eat rice cooked by a Brahmin, but Brahmins do not eat rice cooked by Chhetris because Brahmins are purer than Chhetris (Mishra, 2015, p.79).

In the Western Hills of Nepal, where I was researching on changes in women's lives in Nepal as a $\mathrm{PhD}$ researcher in 2009, I interviewed an older "high caste" woman. She was busy cooking but invited me to enter into her kitchen. Just prior to beckoning me to the kitchen, she said:

Nani, because we are similar by caste, you can come to my kitchen. We can hold our conversation there. I won't let members of other caste groups (aru jat) come to my kitchen. It is a high caste's kitchen. Although there is no caste discrimination (jat-bhat) in the public world today, I still maintain it within my home. I have to make food ready before 9 O'clock because my grandchildren go to school. My daughter-in-law would be out to collect fodder at that hour (Mishra, 2011).

A strong sense of caste hierarchy was reflected in her voice. Older women, vexed by various changes in society, were also were frustrated and tense due to caste related changes.

The anxiety of women of not being able to maintain caste purity in the private domain within the context of change was clearly reflected in the personal account of a high-caste octogenarian woman:

During our times even Bhotes (Tamangs) could not enter into our kitchen with ease even though they were pani 
chalne jat (water-touchable caste group). There was no question then of the sano jat (Dalits) entering the kitchen. Now, there is no jat (caste, ethnicity) at all. Who is sano jat and who is thulo jat, all have become sarobar (equal).

But, I don't like ajako chalan (today's custom)".

She pauses and continues, "All these things have happened because Bahuns (Brahmins) could not maintain ritual purity...When high-caste people start eating pig's meat and alcohol, how could the caste system remain intact o its own? (Mishra, 2015, p. 81).

Caste and gender relations are maintained, negotiated and reproduced through the observation of purity and pollution in the kitchen, in the worship room, during menstruation and marriage and a host of other locations and contexts. Even as all social relations are structured, the agency of women remains on the forefront while implementing these regulations. For example, the purity of the kitchen is reproduced through women's incessant interaction and negotiation with the rules and other users of the kitchen. Women are socialized to learn kitchen norms and practices in varied ways by their mothers and grandmothers in particular. In addition, most "high caste" women think that they should maintain ritual purity and socialize children on cultural and ritual knowledge and practice. They fear that they otherwise would be blamed for the resulting "loss of culture". They would be considered unwomanly and disloyal to the household and kinship circle.

There has been a large-scale transition in women's lives in contemporary Nepal as more women can learn, earn and lead than ever before. It has been possible because of key structural changes in society as reflected in the series of constitutions of 1991, 2007 and 2015 which has resulted in a series of new broadly women-friendly legal measures. These political changes have, of course, led to more pronounced changes in the public sphere than at home. The kitchen, where caste-based purity and pollution has been acted out and reproduced through centuries, is likely to continue to serve as a women's domain for a long time to come.

Most women, although they occupy a mostly subordinate position, are not agency-less as many feminists claim. Women know well how to play the rules to their advantage in order to make their life more secure within patriarchal households. Women most often do not seek to dismantle patriarchy. But they do seek to lead more secure and easier lives (Bhadra \& Mishra, 2009). As a result, women more than men, adhere to caste and ethnic cultures and rituals. As they maintain the rules of caste, they also socialize their daughters and granddaughters to accept the rules.

On the other hand, not all young women accept the rules easily. During my fieldwork in Hetauda in the Central Inner Tarai in 2013, I organized a focus group discussion with 10 young women who were studying at Grade 12 . Caste was one of the key issues discussed. Deepa, an 18-year-old Brahmin woman, noted:

For years ago, when I was 14, I tried to take my Dalit friend to my kitchen. However, my mother stopped her from entering the kitchen. My mother told me that I could bring her to our home and to my room but not the kitchen. At that time, I was angry with my mother. Now I realize my mother was relatively liberal because most households in our village do not allow a Dalit to enter the rooms as of yet.

Clearly, there is a sharp tension here between rebellion and acquiescence and, possibly more importantly a sense of unease and uncertainty even among the younger generation. The trend is toward a relaxation of old rules. But it is not possible to tell if the trend will hold.

Because young women are more educated, informed and employed than the women in the previous generation, they find it easier to change some of the rules. Nonetheless, they often retain the core caste value that a home and kitchen should be a ritually pure place and women should take the prime responsibility for keeping them that way. The women also hold contradictory views about the caste system. For example, they refuse to equate "lower caste" persons with "lower strata" persons because many are their school or work friends. On the other hand, the "higher caste" women do not fully accept "lower caste" women, the Dalit women in particular as equals in all respects because caste rules are ingrained in them.

\section{Rules and Practices of Caste-based Occupation}

The strength and durability of rules governing castebased occupation is one of the key strengths of the caste system. To a large extent, the maintenance of caste-based occupation depends on women (Dube, 1997, p. 2). "Uppercaste" women play an indirect role in maintaining such occupational rules while "lower caste" women are directly involved. For example, some Brahmins are priests by occupation. Priests are exclusively men - although there are a few women priests now. Women as wives, mothers and daughters play a significant role in maintaining the "Brahminhood" of their men. They cook caste-sanctioned "pure' food for their husbands and sons. An overwhelming majority of women cooks and feeds their family members including their husbands (Acharya \& Shrestha, 2018). They follow almost all the old rules of purity and pollution. Sometimes wives and other women in the household even force their priest husbands to live up with the rules not the least because priesthood, the principal component of livelihood, would come under risk should the old rules be evaded or opposed. Women are anxious about their men distancing from their caste-based characteristics. Many women make the argument that if they, as women, do not strictly follow the rules their men would become freer and more independent of them. In order to preserve Brahminhood of their husbands and sons as also to keep husbands and sons within bounds, women strictly observe caste-based rules.

On the other hand, lower caste women are directly involved in the perpetuation of caste-based occupation. Their involvement, however, differs widely by generation 
and gender. For example, I met two "lower caste" daminis (Dalit women tailors), a mother-in-law and her daughterin-law, during my fieldwork in Daanchhi Village on the outskirts of Kathmandu City in 2009. They lived under the same roof but maintained separate households. The women carried on the traditional tailoring occupation. The husband of Jamuna, the daughter-in-law, worked in a bank in Kathmandu. During one of my visits, I also met her husband. He told me he did not want his wife to continue her line of work. He noted,

I have repeatedly asked her to quit this occupation. This occupation is oppressive. I don't like being tied up in patron-client relations. Previously we had no option. We were forced to work for the jajaman (patron). That is not the case any longer. However, she does not listen to me. It is very difficult to convince these illiterate women. (However, he himself had only six years of schooling while his wife was in school for three years.)

Jamuna, in consequence, said:

I have been tailoring since I was a child. I learnt the skill from my parents and continued the work after marriage. My parents-in-law still do the job though they are getting older. I earn for myself through this work. I don't need to ask to anyone for money in order to meet personal expenses. Through this income I also support the household by buying vegetables and sometimes paying for our girls' schooling. These days, other non-patron households also come to make dresses. I hope to earn more from this work. My husband does not understand these things. My 17-year old daughter, who is at Grade 11, also does not like my work. They think this is a lower caste job. They think patrons exploit us. Therefore, we need to quit the occupation. However, the patrons are not as oppressive as it is made out to be. Second, I earn from the work. I, therefore, do not listen to them.

Dhanaman, the father-in-law of Jamuna who continues with tailoring, notes that the professional tie up among the Dalit and non-Dalit household under which the former provided specific services to the latter for an annual return (i.e. the jajmani system) will come to a close with the death of the oldest generation. But he was not happy with the change. Nor was Saraswati, his wife (Mishra, 2011).

Rules of caste-based occupation have eroded rapidly over the last few decades. The younger generation is going through many more years of schooling compared to the older one. The economy is diversifying. The old castebased occupations do not pay as well. As indicated in the previous life story, younger Dalits are reluctant to continue with caste-based occupations. Among others, they think that older occupations entail caste exploitation. It is also the case, on the other hand, the priestly occupation followed by the "high caste" Brahmins does not often pay adequately either.

Due to the recent socioeconomic changes that enable a person to become educated and to take up other nontraditional livelihood options, men and younger generation women tend to opt out from caste-based occupations. On the other hand, for older and middle-aged women, holding on to the traditional occupation remains a viable option. The trend, however, indicates that it would be very difficult to fortify the future of the caste system through the maintenance of caste-based occupations. A substantial proportion of men have begun to regard the old gender norms as discriminatory. The younger generation of women, more importantly perhaps, are actively resisting it. This is not quite the case with the older and middle-aged women but the future is constituted by the young than the old.

\section{Menstruation}

Women's power of fertility, which biologically begins with menstruation, and caste system are closely interlinked. In a caste-based patriarchal society, unless a woman's sexuality is controlled, there is always a chance of an "impure descent" - and hence of the "mixing of castes" and the collapse of kinship as well as the caste system altogether. Chakravarti (2004) discusses the tension among "high caste" households regarding of the mixing together of castes, particularly that of "high caste women" with "lower caste" men. The 1854 Public Laws of Nepal clearly spell out rules controlling women's sexuality. One mechanism of control of sexuality and purity of caste and was early marriage (Hofer, 2004). Other mechanisms are incessant pre-pubertal and pubertal rituals and the gendered messages they carry. In consequence, women more than men, adhere to caste-based rituals (Chae, 2001/2002). Women also transfer caste and gender "knowledge" and rituals to next the generation (Mishra, 2015, p. 97). The "knowledge" and rituals bear a powerful gender message. The message that is imparted by adult women - mothers, grandmothers and aunts - consists of the knowledge and skills that a girl should learn to become a dutiful wife and a caring mother during their later lives. In particular, they should learn to differentiate between a bad woman and a good woman and affirm the later bot in ideals and practice.

Muna Kumari, an older Brahmin woman from the Western Hills, is attuned to the social notions of purity and pollution. She shares her view on menstrual pollution and emphasizes on women's role as preserver of caste in the following way:

It is believed that a daughter's menstrual blood affects the natal relatives (maiti) negatively. Therefore, a woman should refrain from men during their periods. Women should follow the rule of exclusion during menstruation. Men do not like this. If a man tries to touch a woman and wishes to have sex with her, it is the women who should stop it. The menstrual blood is their curse (paap). Women should be very conscious about observing the rules. Men do not abide by them. They are free to break the rule. (Mishra, 2011)

Dalit women share a similar view. "I strongly believe that menstrual blood is impure and a menstrual woman is dangerous," an older Dalit woman from the Western Hills told me. She added:

This is my home, and I have maintained the rules in the fear that god may punish me otherwise. But my daughters-in-law do not follow the rules. They cook 
and do everything even when they are in their period. I suspect that they even share the bed with their husbands. I have tried to remind them many times but they don't listen. They appear destined to do so. It is they who will have to suffer, not me. (Mishra, 2011)

This goes to show how deeply older women have internalized menstrual norms and, in doing so, unknowingly perpetuate the system of patriarchy.

Menstrual rules, however, have also been changing. Rules governing the nature and intensity of the pre and post pubertal rituals such as guneau-cholo, worshipping of virgin girls during kanya puja in Hindu families, offering grown-up, gendered and sexuality-controlling clothing (achara, chunari) to pubertal and bel bibaha - a mock wedding ceremony for a Newar girl, menstrual exclusion and celebration, etc., have been changing during the recent past.

There is also a significant change in the perception and practice of menstruation. This change can be distinctly observed in the beliefs and practices among younger women. They defy many rules of exclusion. The rishi panchami rituals prescribe that purification from sin requires penance and fasting. Even priests, who are the guardians of such rules and prescriptions, are becoming "softer" in the interpretation of such rules, rituals and practice. During recent years, writings and activism from young women in particular have been effective in breaking the silence that ruled over these matters.

On the other hand, notwithstanding changes in the perception and practice of menstruation, the core value that menstruation is impure is relatively intact in all caste groups. This is reflected in the younger women's fear of god if and when rules are defied (Mishra, 2011). Similarly, menstruation is closely related to women's sexuality and mobility. Sexuality has been narrowly defined as sex, and procreation is considered a private matter. It is discussed at home with women - mothers, aunts and grandmothers, etc. Young women are socialized not to discuss the matter with men in in public. Adult women, therefore, become the sole socializers. In the process they teach younger women not only about the exclusionary rules of menstruation, but also impart lessons of becoming a dutiful wife and good mother. Most women, in consequence, come to believe that they voluntarily control their sexuality.

To summarize, even as one can discern both continuity and change in the observation of norms as well as actual practices in relation to menstruation. Structural changes, e.g. mobility, urbanization, schooling, access to information on menstruation as a biological phenomenon are pushing towards change. On the other hand, values that have become ingrained through socialization - that menstruation is decidedly impure - strengthens the continuity of older patriarchal norms and practices.

\section{Marriage}

Caste continues to play a major role in marriage in all caste and ethnic groups. Although inter-caste marriage seems to be increasing and families are accepting this trend to some extent, tension continues to prevail among householders regarding inter-caste marriage. "High caste" women feel a higher level of tension because they are considered the preserver of sexual purity of women as well as the legitimacy of the caste system. Most other women also hold similar views. For example, Kham Maya Magar, 65, from the Western Hills became annoyed when her granddaughter told her that she did not care much about caste while choosing a groom (Mishra, 2011). The old lady said to her granddaughter; "If you chose to marry out of our caste, we will outcaste you. We will think an egg has broken down". The implication was that should the granddaughter marry out of the caste group, she would be considered as good as dead. However, granddaughter Lila, who was 16 , seemed unperturbed by her grandmother's ire. Instead, she was laughing at it.

The conversation suggests that there is huge intergenerational change in visions of the caste system and one's place within it. Young women are more liberal in terms of caste, marriage and friendship with men. On the other hand, it also creates tension in households and among relatives. It is reflected in the expression of a "high caste" and upper class woman in her late sixties in a recent study in a village of central Inner Tarai:

The cell phone is a prostitute. It has come to this village to ruin our daughters and granddaughters. We can't control them these days. Because, with mobile phones, young women are free to talk with anybody they like to. School does not make a woman chhada (erotically less inhibited). We know at what time they are coming back home. But with this mobile phone, they are out of our control (Mishra, 2018, p. 446).

The views of the rural residents including adult women in the central Inner Tarai village show the depth of the tension. Caste continues to be a salient institution (Mishra, 2018, pp. 448-449). When a love marriage takes place, people inquire if the marriage is an endogamous one, people often exclaim: Jat ta milneynai raichha (at least the marriage is caste endogamous). However, inter-caste marriages do take place in the village. And, the statement that is often made in such instances is: Jat namilaypani, panichalne jat rahechha, paninachalnai vayako vaiya ka garnu (At the least this marriage is within the watertouchable group; what would have happened had the marriage brought together water-touchable and water untouchable persons?) In this way, inter-caste marriage has been interpreted and accepted to a level. Marriage between a Dalit and a non-Dalit, on the other hand, was completely rejected even though there were a few cases of marriage between the Dalits and non-Dalits there. The recent initiative of the government of Nepal to incentivize such marriage by awarding Rs. 100,000 (approximately 1,000 US dollars) has not had much effect on promoting such marriage in this village. It indicates that the Dalitnon-Dalit chasm is much too wide to be bridged even with this incentive.

The entry of a "lower caste" bride in a household brings in a host of challenges. It challenges the caste status of a 
household and often forces a break within a household in relation to caste affiliation. This has definite consequences for entry of a household member into the wider kinship network and within the patriline.

Structures and values that uphold caste endogamy continue to remain strong. On the other hand, there are increasingly incidences of both inter-caste and love marriage. Both forms of marriage are acquiring increasing acceptance and legitimacy. However, the gulf between the Dalits and non-Dalits continues to remain wide and deep such that Dalit-non-Dalit marriage continues to be very strongly tabooed.

\section{Conclusion}

Large-scale socioeconomic, political and legal changes, sharply increased schooling and access to information, migration and mobility, urbanization, outside-home work, etc. have unleashed a host of changes in patriarchy and gender in general. These changes have also led to changes in norms and practices related to notion of purity and pollution in the kitchen as well as in menstruation and marriage. Further, these changes have also been instrumental in altering the regime of castebased occupation both among men and women.

As Beteille (1990) argues that, gender asymmetrical societies allow "higher caste" men to abuse "lower caste" women. On the other hand, as long as men's economic, social and political privileges prevail, women of both lower and higher caste would remain in subordinate position. The caste system is also linked to women's economic dependency on men. If women become economically independent, they would perhaps not play the roles they do in order to sustain caste and patriarchy.

Ambedkar (as cited in Aloysius, Mangubhai \& Lee 2011, p.1) notes that Dalit women's empowerment is the key to engage in a struggle against the caste system. Women, Ambedkar reasons should become conscious of their subordination in order to fight against caste and gender discrimination. Education, skills and employment help empower women of all caste groups. During the 1970s, self-realization or consciousness-raising became a major strategy of feminism in order to bring women out of patriarchal control both ideologically and materially (Hooks, 2015). This strategy could also be employed in order to empower Dalit women.

Rege (1998, p. 39) blames mainstream white feminists for being reluctant to address the challenges posed by Black and Third world women. She notes that this reluctance is largely due to Western white feminists' anxiety of being seen as possessing a racist bias inasmuch as a concern with Black and Third World feminism by white women could be seen as a racist overreach. The idea was that the Black and Third World women should speak for themselves. In addition, the reluctance was also due to a fear of radicalizing the mainstream white feminist movement. There is, to some extent, a parallel here in Nepal as well. The mainstream feminist movement in Nepal has been blamed for ignoring the issues that cames out of the struggles of Dalit and Janajati women (Tamang, 2009). It is imperative, therefore, to address Dalit women's issue in the mainstream feminist movement in Nepal. Mainstream feminist movement could take a major role in empowering Dalit women by actively engaging in Dalits' issues as one of the core issues of the movement.

Despite large scale changes following 1990 and the resulting weakening of both the caste system and patriarchy, one can only borrow Dube's word (1997, p. 21) and declare, "Caste is not dead. Gender is a live issue". That does not, on the other hand, imply that the caste system and patriarchy remain intact as some believe. Women's role in sustaining caste and patriarchy is also characterized both by continuity and change.

\section{Ethical Issue:}

I declare that this research has been conducted ethically.

\section{References}

Acharya, M. \& Shrestha, S. (2018). "Introduction". In Meena Acharya (ed.) Women in Unpaid Care Work (pp A-S). Asmita publication.

Adhikari, J. \& Hobley, M. (2015). Everyone is leaving-Who will sow our field? The livelihood effects on women of male migration from Khotang and Udaypur Districts, Nepal to the Gulf countries and Malaysia. Himalaya: Himalayan Journal of the Association for Nepal and Himalayan Studies, 35(1), 11-23.

Aloysius, I. S. J., Mangubhai, J. P., \& Lee, J. G. [eds.]. (2011). Dalit women speak out: caste, class and gender violence in India. Jubaan.

Bennett, L. (1983/2002). Dangerus wives and sacred sisters: Social and symbolic roles of high-caste women in Nepal. Mandala.

Beteille, A. (1990). Race, caste and gender. Man, New Series, 25(3), 489-504.

Bhadra, C. \& Mishra, M. (2009). Women's agency and structural change: theoretical discourse with Nepalese experience. Hamro Sansar: A World of Our Own: A Journal of Women's Studies, (6),

Cameron, M. M. (1998/2005). On the edge of the auspicious: Gender and caste in Nepal. University of Illinois and Kathmandu: Mandala.

Centra; Bureau of Statistics [CBS]. (2012]. National population and housing census 2011. Central Bureau of Statistics. Author.

Chae, M. H. (2001/2002). Gender and ethnicity in identity formation.' The New Jersey Journal of Professional Counseling, 56(23)

Chanana, K. (2001). Hinduism and female sexuality: Social control and education of girls in India. Sociological Bulletin, 50(1), 37-63, 271-95.

Chowdhry, P. (1997). Enforcing cultural codes: Gender and violence in North India. Economic and Political Weekly, XXXII(19)

Chowdhry, P. (2009). First our jobs, then our girls: The dominant caste perceptions on the 'Rising Dalits'. Modern Asian Studies, 43(2), 437-479 
Datta, A. (2015). Recasting caste: From the sacred to the profane by Singh, Hira. The Canadian Journal of Sociology, 40(1), 123-126.

Dube, L. (2001). Anthropological explorations in gender: Intersecting fields. Sage.

Dube, L. (1997). Caste and women. In M. N. Srinivas (ed.) Caste: Its twentieth century avatar (pp 1-27). Penguin Books.

Ghimire, D. J., Axinn, W. G., Yabiku, S. T., \& Thornton, A. (2006). Social change, pre-marital non-family experiences and spouse choice in an arranged-marriage society. American Journal of Sociology, 111(4), 11811218.

Hofer, A. (2004). The Caste hierarchy and the state in Nepal: A study of the Muluki Ain of 1854 (2nd ed.). Himal.

Hooks, B. (2015). Feminism is for everybody: Passionate politics. Routledge.

Khanna, R. \& Price, J. (1994). Female sexuality, regulation and resistance. Focus on Gender, 2(2), 29-34.

Kondos, V. (2004). On the ethos of Hindu women. Issues, taboos and forms of expression. Mandala.

Lerner, G. (1987). The creation of patriarchy. Oxford University.

Mishra, C. (2013). Samriddhi and Uahar. (Prosperity and the Urban.) Kantipur Daily (in Nepali) November 13:7.

Mishra, M. (2019). Livelihoods, households and womanhood in Nepal. In L. Lindsey \& N. Mehrangiz (eds.), Women of Asia: Globalization, development and social change (p. 294-306). Routledge.

Mishra, M. (2018). Sexuality in the making: Nepali rural women's experience. In Dilli Ram Dahal, Laya Prashad Uprety \& Bipin Kumar Acharya (eds.) Current dynamics in transforming Nepal (pp. 439-453). Adroit Publisher

Mishra, M. (2018). Womanhood in making: Women, sexuality and change in rural Nepal in Contributions to Nepalese Studies (forthcoming in Contributions to Nepalese Studies)

Mishra, M. (2015). Ethnicity and ethnic inequality: Recent interpretations from rural Nepal. Contributions to Nepalese Studies, 42(1), 53-106.

Mishra, M. (2014). Spouse selection in Nepal: Changing experiences and interpretations by generation. International Journal of Development Studies: Current Debates in Development, VI(1), 8-14.

Mishra, M. (2011). Changing construction of womanhood: Images, roles, and relationships. (Unpublished doctoral dissertation). Tribhuvan University, Nepal.

Nath, J. G. (2012). State, religion \& women: Changing pattern of patriarchy in pre-colonial Assam. Proceedings of the Indian Congress, 73, 372-382

Parajuli, L., Upreti, D. \& Onta, P. (2016). Pacchis barsa ko paribartan ko lekhajokha (Evaluation of changes during last 25 Years. In Nepali. Sikshak (Teacher magazine).

Rao, A. (2005). Sexuality and the family form. Economic and Political Weekly, 40(8), 715-718

Rege, S. (1998). Dalit women talk differently: A critique of 'difference' and towards a Dalit feminist standpoint position. Economic and Political Weekly, 33(44), 3946.

Tamang, S. (2009). The politics of conflict and difference

or the difference of conflict in politics: The women's movement in Nepal.' Feminist Review, 91.

Mira Mishra, PhD https://orcid.org/0000-0003-26293908, Professor, Central Department of Home Science and Women's Studies, teaches in the Graduate Program in Gender Studies, Tribhuvan University, Kathmandu. Her research and publications focus primarily on rural change, womanhood and women's sexuality. Her recently published articles include "Ethnicity and ethnic inequality: Recent interpretations from rural Nepal (2015) in Contributions to Nepalese Studies, "Reflections on teaching Women' Studies" in Indian Association for Women's Studies (2017), and "Livelihoods, households and womanhood in Nepal" in Linda Lindsey and Mehrangiz Najafizadeh (eds.), Women of Asia: Globalization, Development and Social Change (2019) in Routledge.

Email: miramishra1@gmail.com 